\title{
Tumour-like Lesions of Oral Cavity: A Clinicopathological Study of 95 Cases
}

\author{
Smita Surendra. Masamatti ${ }^{1 *}$, Alka Vikas. Gosavi ${ }^{2}$ and Kalpana Ranjitsingh Sulhyan ${ }^{2}$ \\ 'Dept. of Pathology, Sapthagiri Institute Of Medical Sciences And Research Centre Bangalore, Karnataka, India \\ ${ }^{2}$ Dept. of Pathology, Government Medical College, Miraj, Maharashtra, India.
}

\begin{abstract}
Background: Tumourlike lesions or reactive lesions of the oral cavity are group of fibroconnective tissue lesions that commonly occur in the oral mucosa as a result of injury. Aim: The purpose of this study is to determine the relative prevalence of different histopathological aspects of oral soft tissue tumourlike lesions which were received at Pathology department, Government medical college, Miraj, Maharashtra

Methods: A total number of 95 cases of tumourlike lesions were included in the study. Specimens were received at department of pathology, Government medical college, Miraj, Maharashtra over a period of 5 years from August 2008 to July 2013. It was one year retrospective and four years prospective, cross sectional study

Result: A total number of 642 oral biopsies and excised specimens were studied, out of which 95cases (14.8\%) belonged to tumourlike lesions. Among tumorlike lesions, pyogenic granuloma (47.38\%) was the commonest lesion, followed by Mucocele (26.32\%). Majority of tumorlike lesions were located on gingiva (38.94\%) followed by lower lip (28.42\%). Males $(57.89 \%)$ were more commonly affected than females and the commonest symptom was swelling (100\%).

Conclusion: The most common tumourlike lesion in our study was pyogenic granuloma. Few very rare and interesting cases like plasma cell granuloma and Nasolabial cyst were also seen. Tumorlike lesions presented mainly as nodule or swelling, which should be differentiated from other benign and sometimes malignant lesions, as the tumourlike lesions have good prognosis when compared to malignant lesions. Hence histopathology remains the mainstay for correct diagnosis and treatment.
\end{abstract}

Keywords: Oral Cavity, Pyogenic Granuloma, Reactive Lesion, Tumourlike Lesion

\section{Introduction}

The term "soft tissue tumour" includes a different group of neoplastic and reactive lesions which are derived from supporting mesenchymal or connective tissues of the body. These consist of tumours made up of fibrous tissue, fat, muscle, nerves and blood vessels. ${ }^{[1]}$ In oral cavity, mastication makes it susceptible for different types of trauma and injury, also the presence of teeth and odontogenic tissue is adding more liability for variety of diseases which vary from, simple inflammatory disease to highly malignant tumours. ${ }^{[2]}$

Tumourlike lesions of oral cavity are not included in the WHO classification 2005. However the previous WHO classification 1971 by P.N. Wahi et al included these lesions in their classification. According to this classification, the various tumourlike conditions listed are, Verruca vulgaris, Papilliferous hyperplasia, Mucocele, Nasolabial cyst, Fibrous overgrowth, congenital fibromatosis, Xanthogranuloma, Pyogenic granuloma, Peripheral giant cell granuloma (Giant cell epulis), Traumatic neuroma, Inflammatory pseudotumour (Plasma cell granuloma). ${ }^{[3]}$
Although these lesions are benign in nature, they do have a tendency towards recurrence with incomplete removal of the lesion or the local irritants involved at the site. The treatment in each case is complete surgical excision, however nowadays different treatment modalities are available which offers better outcomes with less chances of recurrence. ${ }^{[4]}$

The various tumourlike lesions in the present study were pyogenic granuloma, mucocele, plasma cell granuloma, nasolabial cyst, fibrous epulis and giant cell fibroma. The present study reviews the various clinical and histopathological features of all these six types of reactive lesions and establishes the relative prevalence of different tumourlike lesions in relation to age, gender and site in oral cavity.

\section{Materials and Methods}

The present study consisted of analysis of tumourlike lesions of oral cavity received in the histopathology section of department of pathology at Government medical college, Miraj, Maharashtra over a period of 5 years that is from August 2008 to July 2013. This was one year 
retrospective and four years prospective study. Patients data were assessed to collect data including, age, gender, affected site clinical presentation, personal habits and clinical diagnosis. The material comprised of oral biopsies and excision specimens.

\section{Inclusion criteria}

1. Tumorlike lesions of oral cavity.

2. Specimens which were adequate and representative of the lesion.

3. Resected surgical specimens like wide local excision, incisional biopsies, wedge biopsies etc

\section{Exclusion criteria}

1. Inadequately preserved specimens.

2. Neoplasms arising from nasopharynx and oropharynx

3. Neoplasms of odontogenic origin.

4. Bone tumours of mandible and maxilla.

\section{Result}

During the five year interval, 95 tumorlike lesions were recorded from a total oral biopsy of 642 cases. This constituted about $14.79 \%$ of total oral biopsies. The age range of the patients was from 8 to 73 years and the mean age was 30 years. Most of the lesions (36.84\%) were found in the third decade of life. Males constituted $57.89 \%$ of the cases and $42.11 \%$ of the lesions were found in females. The most affected anatomic location was Gingiva (38.94\%) followed by lower lip (28.42\%).

Pyogenic granuloma (PG): There were 45 cases of PG, maximum no of cases occurred between second and third decade. Maximum no of PG (48.88\%) were located on gingiva, with female preponderance of $64.45 \%$. Grossly the size of $P G$ ranged from $0.3 \mathrm{cms}$ to $2.5 \mathrm{cms}$. Histologically all PG showed numerous small and large vascular channels which are engorged with RBCs and lined by flat or plump endothelium. Polymorphs as well as chronic inflammatory cells were also seen. (Figure 1)

Mucocele: In the present study, 25 mucocele cases were encountered. The peak incidence was found in $2^{\text {nd }}$ and $3^{\text {rd }}$ decade with slight male preponderance of $52 \%$. Lower lip was commonest site (48\%). Grossly all of them were, dome shaped mucosal swelling ranging from 1 to $2 \mathrm{~mm}$ to several centimeters in size. Microscopically they were classifed as 1) Extravasation type \& 2) Retention type. Extravastion type showed foci of stromal reaction due to spillage of mucous from a traumatically injured minor salivary gland where as retention cyst shows mucous filled cyst completely lined by cylindrical, cuboidal or flattened cells. (Figure 2)

Nasolabial cyst (NLC): One case of NLC was encountered as incidental finding. Patient was 63 year old female who presented with fluctuant, soft, cystic mass on left gingivolabial sulcus measuring about $2 \times 2 \mathrm{cms}$. Microscopy revealed cyst lined by pseudostratified columnar epithelium. Numerous goblet cells were seen. (Figure 3)

Plasma cell granuloma (PCG): One case of PCG was observed in a 58 year old female, presented with polypoidal mass over gingiva. Radiological and serum electrophoresis were normal. Grossly the mass measured $3 \times 2 \mathrm{cms}$, cut surface showed whitish appearance. Histologically the mass was covered by stratified squamous epithelium \& was composed of aggregates of spindle cells separated by thick collagen bundles. Many Russell bodies were noted. (Figure 4)

Fibrous epulis (FE): There were 18 cases of FE which showed a peak incidence in $4^{\text {th }}$ decade $(55.55 \%)$ with slight male preponderance. Gingiva was the most common site (61.11\%). On gross examination, all cases presented as nodular lesions. Microscopically the mass was covered by stratified squamous epithelium and composed of proliferating fibroblasts arranged haphhazardly and at places in short bundles. Foci of clacification were also noted in few cases.

Giant cell fibroma (GCF): Five cases of GCF were encountered during the study period. Majority of them showed male preponderance $(80 \%)$ and maximum no of cases occurred in gingiva $(60 \%)$. Histologically all GCF showed mass covered by stratified squamous epithelium and was composed collagenous stroma with many scattered stellate shaped fibroblast.

Table 1: Broad classification of tumourlike lesions of oral cavity along with genderwise distribution.

\begin{tabular}{|c|l|c|c|c|}
\hline SI.no & Type of tumourlike lesion & Males & Females & Total no of cases (\%) \\
\hline 1 & Mucocele (Extravasation and retention type) & 13 & 12 & $25(26.32 \%)$ \\
\hline 2 & Pyogenic granuloma & 16 & 29 & $45(47.38 \%)$ \\
\hline 3 & Plasma cell granuloma & -- & 01 & $01(1.05 \%)$ \\
\hline 4 & Nasolabial cyst & -- & 01 & $01(1.05 \%)$ \\
\hline 5 & Fibrous epulis & 10 & 8 & $18(18.94 \%)$ \\
\hline 6 & Giant cell fibroma & 04 & 01 & $05(5.26 \%)$ \\
\hline TOTAL & $\mathbf{4 3}$ & $\mathbf{5 2}$ & $\mathbf{9 5 ( 1 0 0 \% )}$ \\
\hline
\end{tabular}


Table 2: Agewise distribution of tumourlike lesions of oral cavity.

\begin{tabular}{|c|c|c|c|c|c|c|c|c|}
\hline \multirow[b]{2}{*}{ SI.no } & \multirow{2}{*}{$\begin{array}{l}\text { Age in } \\
\text { years }\end{array}$} & \multicolumn{7}{|c|}{ Tumourlike lesions of oral cavity } \\
\hline & & Mucocele & $\begin{array}{l}\text { Pyogenic } \\
\text { granuloma }\end{array}$ & $\begin{array}{l}\text { Plasma cell } \\
\text { granuloma }\end{array}$ & $\begin{array}{c}\text { Nasolabial } \\
\text { cyst }\end{array}$ & $\begin{array}{l}\text { Fibrous } \\
\text { epulis }\end{array}$ & $\begin{array}{l}\text { Giant cell } \\
\text { fibroma }\end{array}$ & Total \\
\hline 1 & $1-10$ & 5 & 03 & -- & -- & -- & -- & $08(8.55 \%)$ \\
\hline 2 & $11-20$ & 7 & 10 & -- & -- & 02 & 01 & $20(21.05 \%)$ \\
\hline 3 & $21-30$ & 10 & 20 & -- & -- & 03 & 02 & $35(36.84 \%)$ \\
\hline 4 & $31-40$ & 02 & 07 & -- & -- & 10 & 01 & $20(21.05 \%)$ \\
\hline 5 & $41-50$ & -- & 04 & -- & -- & 01 & 01 & $06(6.31 \%)$ \\
\hline 6 & $51-60$ & -- & -- & 01 & -- & 01 & -- & $02(2.10 \%)$ \\
\hline 7 & $61-70$ & -- & -- & -- & 01 & 01 & -- & $02(2.10 \%)$ \\
\hline 8 & $>70$ & -- & 01 & -- & -- & -- & -- & $01(1.05 \%)$ \\
\hline \multicolumn{2}{|c|}{ Total } & 25 & 45 & 01 & 01 & 18 & 05 & $95(100 \%)$ \\
\hline
\end{tabular}

Table 3: Distribution of various clinical features of tumourlike lesions of oral cavity.

\begin{tabular}{|c|c|c|}
\hline SI.no & Symptoms & Tumourlike lesions . No ( \%) \\
\hline 1 & Swelling/nodular lesion & $95(100 \%)$ \\
\hline 2 & Pain & $55(57 \%)$ \\
\hline 3 & Difficulty in chewing & $48(50.5 \%)$ \\
\hline 4 & Excessive salivation & $15(15.7 \%)$ \\
\hline
\end{tabular}

Table 4: Sitewise distribution of tumourlike lesions of oral cavity.

\begin{tabular}{|c|c|c|c|c|c|c|c|}
\hline SI.no & Lesions & Buccal mucosa & Tongue & Gingiva & Floor of mouth & Lower lip & Total \\
\hline 1 & Mucocele & 05 & -- & -- & 08 & 12 & 25 \\
\hline 2 & Pyogenic granuloma & 07 & 01 & 22 & -- & 15 & 45 \\
\hline 3 & Plasma cell granuloma & - & -- & 01 & -- & -- & 01 \\
\hline 4 & Nasolabial cyst & 01 & -- & -- & -- & -- & 01 \\
\hline 5 & Fibrous epulis & 04 & 03 & 11 & -- & -- & 18 \\
\hline 6 & Giant cell fibroma & 01 & 01 & 03 & -- & - & 05 \\
\hline & Total & $\mathbf{1 8 ( 1 8 . 9 4 \% )}$ & $\mathbf{0 5 ( 5 . 2 6 \% )}$ & $\mathbf{3 7 ( 3 8 . 9 4 \% )}$ & $\mathbf{0 8 ( 8 . 4 2 \% )}$ & $\mathbf{2 7 ( 2 8 . 4 2 \% )}$ & $\mathbf{9 5 ( 1 0 0 \% )}$ \\
\hline
\end{tabular}

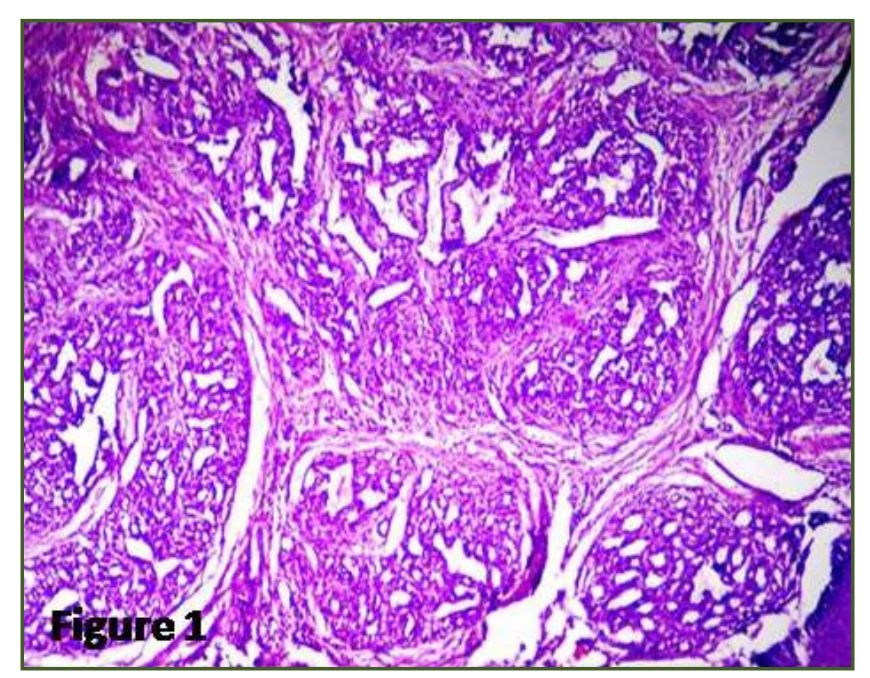

Fig. 1: Pyogenic granuloma showing many capillary sized blood vessels.( H \& E, x100). 


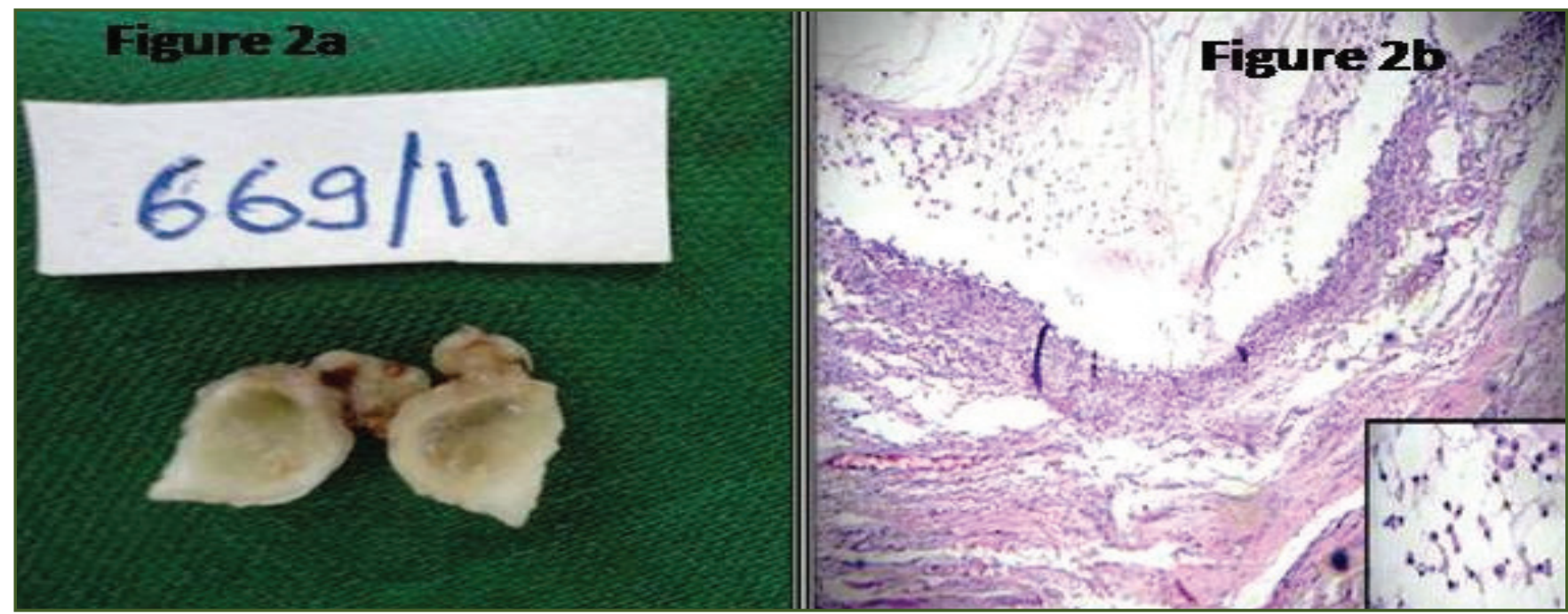

Fig. 2: a) Gross picture of Mucocele of lower lip, cystic swelling. b) Low power showing cyst lined by granulation tissue. Cavity shows mucin associated with foamy histiocytes. Inset shows foamy histiocytes (H \& E, x100).

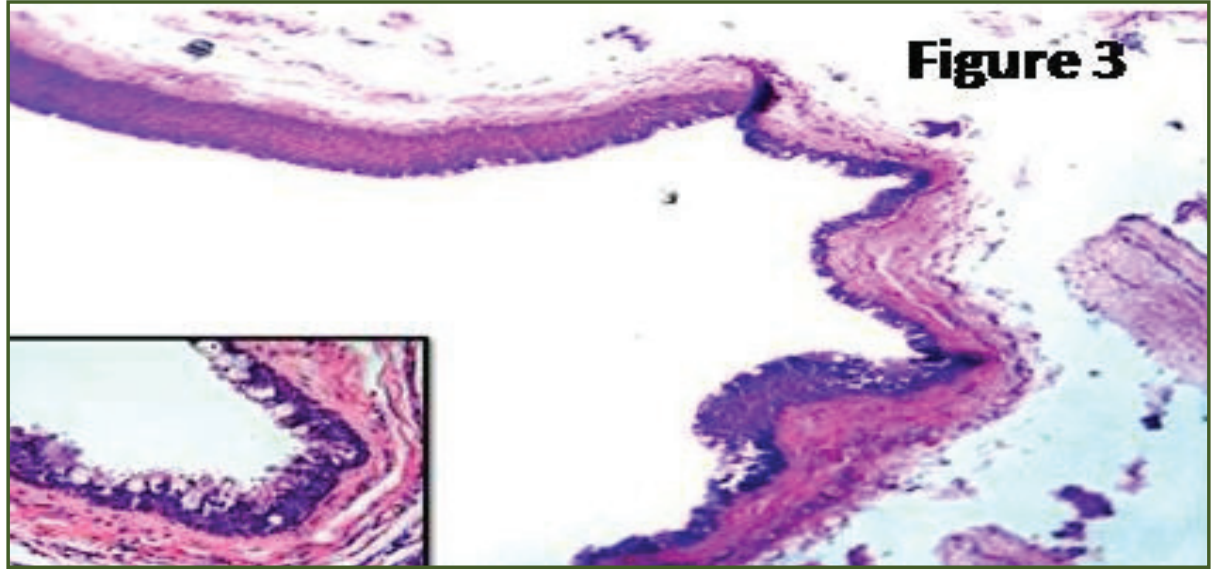

Fig. 3: Nasolabial cyst- Cyst wall lined by pseudostratified columnar epithelium. Inset shows presence of goblet cells in the lining. (H \& E,X100).

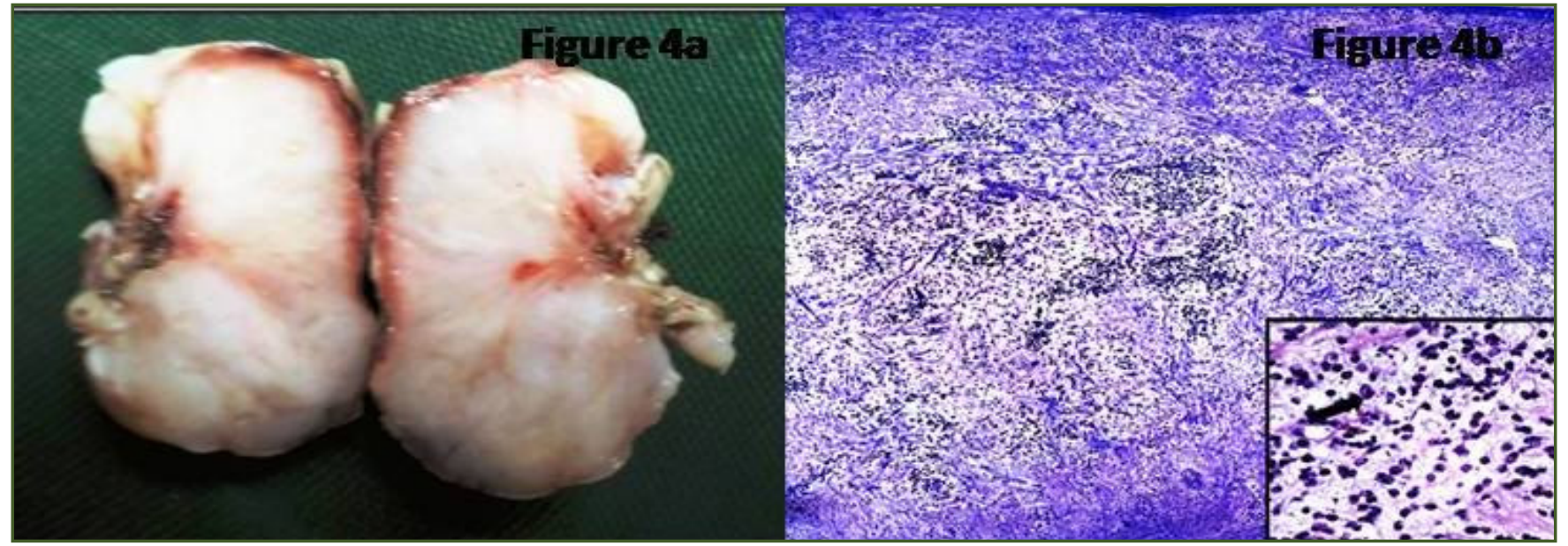

Fig. 4: a) Gross picture of PCG showing solid greywhite cut surface. b) Microscopy showing sheets of plasma cells separated by thick collagen bands. (H \& E, x100). Inset shows Russell bodies, x400). 


\section{Discussion}

The present study findings cannot be exactly compared with other similar studies as there are only few studies reporting the prevalence of oral mucosal lesions around the world and also the difference is attributed to the given geographic area. The study aims to report the prevalence of histopathology of various tumorlike lesions along with its clinical correlation, received at Government medical college, Miraj, Maharashtra. The final outcome of the study shows that the soft hemorrhagic lesions were more common than the fibrous lesions. Pyogenic granuloma was the most common tumourlike lesion. All the six tumourlike lesions in our study are discussed in detail and are compared with other studies.

Pyogenic granuloma (PG): PG is a relatively common entity first described by Poncet and Dor in 1897 as "Human botryomycosis". Hartzell introduced the term 'Pyogenic granuloma' (PG) and some authors used the term 'Lobular capillary hemangioma' (LCH). ${ }^{[5]}$ It accounts for about 1.5 to $2 \%$ of all oral lesions. ${ }^{[6]}$ In 2001, M. Umut Akyol et al reviewed 835 cases in the literature and showed that the prevalent age for the development of pyogenic granuloma appears between 11 and 40 years, and also the most common site was gingiva $(75 \%)$ and less frequently at other sites like tongue. Our findings correlate with this study. ${ }^{[5]}$

Mucoceles are mucous cysts related to obstruction or trauma of the minor salivary glands. ${ }^{[7]}$ They typically appear as dome shaped mucosal swellings that range from 1 to $2 \mathrm{~mm}$ to several centimeters in size. It is often seen in young individuals, the lower lip being the classic location. ${ }^{[8]}$ Oliveira et al studied 112 cases of mucocele and found that extravasation cyst was the most commonly found $(92.45 \%)$ however mucous retention cysts were also observed $(7.54 \%)$. It was most prevalent in the second decade of life $(45 \%)$ and predominant location was lower lip (52.25\%). ${ }^{[7]}$ These all findings correlated with our findings.

Plasma cell granuloma (Inflammatory pseudotumour): Inflammatory pseudotumour (IPT) is a tumourlike lesion. Other synonyms used for this lesion are Plasma cell granuloma, histiocytoma, Xanthomatous granuloma, inflammatory myofibroblastic tumour and spindle cell pseudotumour. The exact incidence of IPT in oral cavity is unclear. ${ }^{[9]}$ Clinicallly and radiographically it may be misinterpreted as a malignant neoplasm. It tends to affect children and young adults. The cheek and mandible are the sites of predilection in oral cavity. ${ }^{[10]}$ But in our study, one case of PCG $(1.05 \%)$ was seen, which presented as a gingival swelling. Kim et al suggested that interleukin-6
(IL-6) and phospholipase C-1 may induce heavy plasma cell infiltration in cyclosporine induced gingival overgrowth. ${ }^{[1]}$ Our patient did not give any history of intake of medicines.

Nasolabial cyst: Nasolabial cyst is a rare non odontogenic tumour arising from maxillofacial soft tissues. They represent about $0.7 \%$ of all cysts in the maxillofacial region and $2.5 \%$ of all non odontogenic cysts. ${ }^{\left[{ }^{[2]}\right.}$ This condition was first described by Zuckerkandl in 1882. The various synonyms for nasolabial cyst include Nasoalveolar cyst, Klestadt cyst, Fissural cyst, Non odontogenic cyst, soft tissue cyst. Clinically these cysts are seen in the extraosseous region of the nasolabial fold, projecting over upper lip. It is more common in middle aged females (4:1), usually asymptomatic and unilateral. ${ }^{[13]}$ Lopez Rios et al noticed extensive apocrine change in the lining epithelium. [14] Tiago RS et al observed that most of the patients belonged to age group of above 30 years with a female preponderance and cysts were unilateral in $85 \%$ of the cases, which correlates with our study. ${ }^{[15]}$

Giant cell fibroma (GCF): Giant cell fibroma is a fibrous hyperplastic lesion of oral cavity and has a distinctive clinicopathology unlike traumatic fibroma. GCF is a relatively rare tumourlike lesion that could be diagnosed only on histopathological examination. It was named so due to its characteristically large, stellate shaped, mononuclear and multinucleated giant cells. Sabrinath et al reported that the mean age was 39 years, gingiva being the commonest location and showed slight male preponderance which correlates with our findings. ${ }^{[16]}$

Fibrous epulis: Fibrous epulis is considered to be one of the most common benign growths occuring on gingiva. The lesion is usually located in the premolar area between ages of 21 to 40 years. H.A. Ajagbe observed that the lesions were more common in females than males' correlates with our findings. And also in his study, centres of ossification and calcification were noted, which were not seen in our cases. ${ }^{[17]}$ Buchner et al reported most of the cases to occur in the $3^{\text {rd }}, 4^{\text {th }}$ and $5^{\text {th }}$ decade of life whereas Kfir Y et al found the majority of cases in the $2^{\text {nd }}, 3^{\text {rd }}$ and $4^{\text {th }}$ decade, which correlates with our findings. ${ }^{[18,19]}$

The various results obtained in this study overall confirm with those of other researchers, though slight differences were observed in age and gender distribution. It is helpful to know the various histopathological types and clinical presentation of tumourlike lesions of oral cavity in order to develop a clinical impression of such lesions during practice. And also the data will help the clinicians and pathologists to be aware of possible occurrence of such rare lesions. 


\section{Conclusion}

Tumourlike lesions usually present as swelling or nodule which may mimic benign or malignant lesions clinically and pose a diagnostic problem to the clinicians and pathologists. So all oral lesions should be diagnosed early and subjected for histopathological examination for the correct diagnosis as tumourlike lesions have got good prognosis and doesnot recurr unlike the malignant lesions.

\section{Reference}

1. Shahsavari F, Khourkiaee SS, Moridani SG. Epidemiologic study of benign soft tissue tumors of oral cavity in an Iranian population. Journal of dentomaxillofacial radiology, pathology and surgery. 2012;1(1):10-14.

2. Hassawi BA, Ali E, Subhe N. Tumors and tumor like lesions of the oral cavity. A study of 303 cases. Tikrit medical journal.2010:16(1):177-83.

3. P.N.Wahi. Histological typing of oral and oropharyngeal tumours. Issue 4 of international histological classification of tumours. World health organisation. 1971.

4. Kasyap B, Reddy S, Nalini P. Reactive lesions of oral cavity: A survey of 100 cases in Eluru, West Godavari district. Contemporary clinical dentistry. 2012; 3(3): 294-97.

5. Akyol MU, Yalciner EG, Dogan AI. Pyogenic granuloma (lobular capillary hemangioma) of the tongue. Int J Pediatr Otorhinolaryngol.2001; 58: 239-41.

6. Jafarzadeh H, Sanatkhani M, Mohtasham N. Oral pyogenic granuloma: a review. J oral sci. 2006 Dec; 48(4): 167-75.

7. Oliveira DT, Consolaro A, Freitas FJ. Histopathological spectrum of 112 cases of mucocele. Braz Dent J. 1993; 4(1):29-36.

8. Ackerman L.V. and Rosai. J Oral cavity and oral pharynx. A textbook of surgical pathology. 9th ed. Mosby St Louis: 1996.p-247.
9. Shek AW, Wu PC, Samman N. Inflammatory pseudotumour of the mouth and maxilla. J clin pathol. 1996; 49(2): 164-7.

10. Coffin CM, Fletcher JA, Fletcher C.D.M. , Unni KK, Mertens F(Ed): World health organisation classification of tumours. Pathology and genetics of tumours of soft tissue and bone. IARC Press: Lyon; 2002.p91-3.

11. Kim SS, Eom D, Huh J, Sung I, Choi I, Sung HR et al. Plasma cell granulomas in cyclosporine induced gingival growth; A report of two cases with immunohistochemal positivity of interleukin- 6 and phospholipase C-g. J Korean med sci. 2002; 17: 704-7.

12. Pereira Filho VA, Silva AC, Moraes M, Moreira RW,Villalba H. Nasolabial cyst: Case report. Braz Dent J. 2002; 13(3):212-4.

13. Nasolabial cyst by Dr T. Balasubramanian [internet][Cited on 2014 Oct 20] Available at: http://www.drtbalu.co.in/naso cyst.html.

14. Lopez-Rios F, Lassaletta- Atienza L, Domingo- Carrasco C, Martinez- Tello FJ. Nasolabial cyst: report of a case with extensive apocrine change. Oral Surg Oral Med Oral Pathol Oral Radiol Endod. 1997 Oct; 84(4); 404-6.

15. Tiago RS, Maia MS, Nacimento GM, Correa JP, Salgado DC. Nasolabial cyst: diagnostic and therapeutical aspects. Rev Bras Otorhinolaringol. 2008; 74(1):39-43.

16. Sabrinath B, Sivaramakrishnan M, Sivapathasundharam B. Giant cell fibroma: A clinicopathological study. J oral maxillofac Pathol. 2012; 16(3): 359-62.

17. Ajagbe HA, Daramola JO. Fibrous epulis: Experience in clinical presentation and treatment of 39 cases.

18. Buchner A, Calderon S, Ramon Y. Localized hyperplastic lesions of the Gingiva: a clinicopathological study of 302 lesions. J Periodontol. 1997 Feb; 48(2):101-04.

19. Kfir Y, Buchner A, Hansen LS. Reactive lesions of the Gingiva. A clinicopathological study of 741 cases. J Periodontol. 1980 Nov; 51(11):655-61.

*Corresponding author:

Dr Smita Surendra. Masamatti, DQ 14, Sapthagiri Hospital, Chikkasandra, Bangalore, 560090, India

Phone: +91 9741147555

Email: smitamas@yahoo.co.in

Date of Submission : 22.03.2017

Date of Acceptance : 06.04.2017

Financial or other Competing Interests: None.

Date of Publication : 10.04.2017 